\title{
EFFECT OF GEAR RATIO ON THE DC MOTOR EFFICIENCY OF A MINI- FUEL-CELL VEHICLE CRUISING AT CONSTANT SPEEDS
}

\author{
S. Hanapi ${ }^{1}$, M.H.A Mohd Fakharuzi ${ }^{1}$, A.H. Abdol Rahim ${ }^{1}$, AlHassan Salami \\ Tijani $^{1}$, K.I. Sainan ${ }^{1}$ and W.A.N. Wan Mohamed ${ }^{1}$ \\ ${ }^{1}$ Faculty of Mechanical Engineering, Universiti Teknologi MARA, \\ 40450 Shah Alam, Selangor, Malaysia \\ "Email: suhadiyanahanapi@yahoo.com \\ Phone: +6019-2413600; Fax: +603-5543 5160
}

\begin{abstract}
The traction motor is a key component in a fuel-cell vehicle as it converts electrical energy supplied by a fuel cell into mechanical shaft work for vehicle propulsion. Motor size, torque rating and current consumption are important factors in the selection of the optimum drive motor for best energy efficiency. In a practical power train assembly, the motor is coupled to the wheel via a gearing system. This study focuses on the performance with respect to traction motor efficiency relative to the gear ratio selection and variable drive cycles to minimize the power consumption of the vehicle. A test bench with a $1 \mathrm{~kW}$ fuel cell was developed and tests were performed at constant speeds between $15 \mathrm{~km} / \mathrm{h}$ to $30 \mathrm{~km} / \mathrm{h}$ with different gear ratios. Among the measured and evaluated parameters using Eagle Tree and Inertia data loggers are rpm, current, torque and power. The results show that the gear ratio selection produces a variation in required motor input power at similar drive speeds. It also shows the optimal setting of the gear ratio of more than $70 \%$ that suits the best efficiency point of the DC motor according to actual driving requirements.
\end{abstract}

Keywords: Traction Motor; Efficiency; Gear Ratio; PEM Fuel-Cell Vehicle, Constant Speed.

\section{INTRODUCTION}

The problem of fossil fuel combustion affecting environmental pollution and the greenhouse effect is increasing the demand for the development of clean energy sources. Furthermore, there are increasing demands to reduce global warming and ozone depletion processes related to the use of fossil fuels [1]. Moreover, worldwide oil reserves are depleting, while the demand for energy is increasing on large scales [2]. More than $90 \%$ of the transportation sector is powered by oil derived from nonrenewable fossil fuels [3]. Internal combustion engines rely on fossil fuels such as gasoline and diesel [4-7]. Fossil fuels are a nonrenewable form of energy, which implies that there is a finite amount in the world [8-10]. During the last two decades, considerable research and development (R\&D) activities have concentrated on alternative energy. Thailand is an agricultural country which generates a large amount of various types of biomass, such as bagasse, husk, straw, palm fruit, palm fiber and shell, and coconut shell. These biomasses are renewable energy; however, in order to achieve smooth operation of the engine with the desired power output requirements and to minimize the emissions and fuel consumption, several constraints have to be 
considered in appropriate engine tuning, such as elimination of knocks, pre-ignition, self-ignition and back-firing [3, 7, 11-14]. As an alternative, fuel cells are employed as the power to drive vehicles. A vehicle using a fuel cell to generate electricity to power an on-board electric motor in the vehicle is called as fuel cell vehicle. The proton exchange membrane fuel cell (PEMFC) has the potential to power an electric vehicle due to the high power density, low temperature operating and quick start up which are suited to the vehicle power source. The raw materials are hydrogen, which is ubiquitous, and its reactant, water, which is environmentally friendly; for this reason it is an optimal resource [9, 15-19]. However, there are many issues that have to be addressed before the vehicle becomes widely used. One of the most important issues with regard to the PEMFC vehicle drive train is the electric traction motor. Traction motors should meet requirements such as high instant power, high power density and high torque at low speed for starting and climbing [20]. Apart from the traction motor, another important component related to power performance is the transmission or gearbox in the drive system of the vehicle.

A brushed motor is one of the simplest forms of electric motor. This type of motor is very widely used in applications such as portable tools, toys, electrically operated windows in cars, and small domestic appliances, such as hair dryers, even if they are AC mains powered [21]. The brushed DC motor is a good starting point because, as well as being widely used, most of the important issues in electric motor control can be more easily explained with reference to this type of motor [22]. It is a DC motor, equipped with permanent magnets and brushes. This simplified motor has one coil. The current passing through the wire near the magnet causes a force to be generated in the coil. The two forces cause the coil to turn. The coil turns with the commutator, and once the wires are clear of the magnet the momentum carries it on round until the half rings of the commutator connect with the brushes again. When this happens, the current is flowing in the same direction relative to the magnets, and hence the forces are in the same direction, continuing to turn the motor as before [23]. Commonly, relative to the gear ratio selection, standard advanced vehicles, such as those presented in [24], utilize either single ratio transmissions or direct drive with no gear reduction in delivering the traction load to the road. Consequently, the gear ratio design needs to achieve a balance between the range, performance, and top speed. The appropriate gear sizing affects the overall system efficiency by effecting motor efficiency. The work presented in this paper describes the effect of the gear ratio on DC motor efficiency for the vehicle system in a constant speed condition.

\section{METHODOLOGY}

The term vehicle performance for a fuel-cell vehicle shows the power performance, fuel economy, durability and safety. It is difficult to give a clear definition of the term. Generally speaking, the following indicators are used to evaluate a vehicle: the maximal speed that can be reached, the accelerating time from zero to a certain speed, the maximal climbing angle, the mileage in a certain condition and the hydrogen consumption in a specific cycle. The proposed system design, a vehicle model for a mini PEMFC, is explained. To simulate the motor system we need the parameters of the vehicle. The mini PEMFC vehicle parameters and specifications are reported in Table 1. 
Table 1. Vehicle parameters and specifications.

\begin{tabular}{|c|c|c|c|}
\hline Vehicle parameters & Values & Vehicle parameters & Values \\
\hline Vehicle mass + driver, $m$ & $170 \mathrm{~kg}$ & Drag reference area, $A$ & $0.93 \mathrm{~m} 2$ \\
\hline Angular acceleration mass factor, $\left(\frac{I G^{2}}{\eta_{G} r^{2}}\right)$ & $8.5 \mathrm{~kg}$ & Drag coefficient, $C_{d}$ & 0.27 \\
\hline Actual rolling resistance coefficient, $\mu_{r r}$ & 0.015 & Wheel radius, $r$ & $0.27 \mathrm{~m}$ \\
\hline
\end{tabular}

\section{MATHEMATICAL MODELING}

\section{Vehicle model}

In electric vehicles focusing on the mini PEMFC vehicle system, both mechanical and electrical systems are designed to provide optimal range and performance. The model is used to define the required vehicle output power demand in comparison with the actual data from the experiment. The forces required to propel a vehicle while cruising consist of rolling resistance, aerodynamic resistance and hill climbing resistance. Thus, the cruising power, $P_{c s}$, model becomes;

$$
P_{c s}=\left(F_{r r}+F_{a d}+F_{h c}\right) v=\left(\mu_{r r} m g+0.625 A C_{d} v^{2}+m g \sin \theta\right) v
$$

where $F_{r r}$ is the rolling resistance force, $F_{a d}$ is the aerodynamic force, $F_{h c}$ is the hill climbing force, $\mu_{r r}$ is the rolling coefficient of the tire, $m$ is total vehicle mass, $A$ is drag reference area, $C_{d}$ is the drag coefficient and $v$ is velocity.

Several vehicle speeds and road gradients were chosen for this case study and Table 2 shows the resultant power output based on the power model for each case.

Table 2. Output power at variable constant speed.

\begin{tabular}{lll}
\hline Vehicle Speed & Road Grad $[\% / \mathrm{deg}]$ & Pout $[\mathrm{W}]$ \\
\hline 21 & 0 & 177.08 \\
23 & 0 & 200.75 \\
25 & 0 & 226.28 \\
28 & 0 & 268.41 \\
30 & 0 & 299.28 \\
18 & $2 / 1.15$ & 311.41 \\
15 & $5 / 2.86$ & 462.46 \\
\hline
\end{tabular}

\section{Motor Model}

A brushed DC motor, manufactured by Midwest Motion Products (MMP), was used as the traction motor. In the making of a cruise power model, motor torque and speed should be identified. Table 3 shows the motor parameters given by the manufacturer. The torque is directly proportional to the current while the speed is directly proportional to the voltage. The relationship between torque, speed, current and voltage are as in Eqs. 
(2) and (3) where $I$ is the armature current, $V_{S}$ is the terminal voltage, $R_{a}$ is the armature resistance, $K_{m}$ is the a torque constant, and $\omega$ is the motor angular speed.

$$
\begin{gathered}
\omega=\frac{I R_{a}}{V_{s}-K_{m}} \\
T=I K_{m}
\end{gathered}
$$

Table 3. DC motor specification given by the manufacturer (MMP D40-675F).

\begin{tabular}{ll}
\hline DC motor parameters & Values \\
\hline Motor constant, $K_{m}$ & $0.1624 \mathrm{Nm} / \mathrm{A}$ \\
Supply voltage, $V_{s}$ & $36 \mathrm{~V}$ \\
Armature resistance, $R_{a}$ & $0.24 \Omega$ \\
No load speed, $n_{0}$ & $2120 \mathrm{rpm}$ \\
No load current, $I_{0}$ & $0.61 \mathrm{~A}$ \\
\hline
\end{tabular}

The consideration of a 'no load' condition in the motor model will produce more modeling accuracy. The 'no load' condition represents losses at the highest rotational speed and comprises two elements: 'no load' current and 'no load' speed. Eq. (4) shows the motor power output model implementing the 'no load' condition where, $I_{o}$ is the "no load' current, $n_{l}$ is the speed loss and $T_{f}$ is the torque friction. The data with 'no load' values must be taken from the actual test as, for example, shown in Table 4.

$$
\begin{gathered}
P=\left[\left(\frac{I R_{a}}{V_{s}-K_{m}}\right)-\frac{\pi}{30} n_{l}\right]\left(I K_{m}-T_{f}\right) \\
T_{f}=K_{m} I_{0}
\end{gathered}
$$

Table 4. Measured 'no load' condition for different voltages of the MMP D40-675F.

\begin{tabular}{llllll}
\hline $\begin{array}{l}\text { Voltage } \\
(\mathrm{V})\end{array}$ & $\begin{array}{l}\text { Measured No } \\
\text { Load Current, } I_{o} \\
(\mathrm{~A})\end{array}$ & $\begin{array}{l}\text { Measured No } \\
\text { Load Speed, } \\
n_{o} \\
(\mathrm{rpm})\end{array}$ & $\begin{array}{l}\text { Friction } \\
\text { Torque, } T_{f} \\
(\mathrm{Nm})\end{array}$ & $\begin{array}{l}\text { Theoretical No } \\
\text { Load Speed } \\
(\mathrm{rpm})\end{array}$ & $\begin{array}{l}\text { Speed } \\
\text { loss, } n_{1} \\
(\mathrm{rpm})\end{array}$ \\
\hline 36.0 & 0.76 & 1864.3 & 0.12 & 2116.6 & 252.3 \\
30.0 & 0.71 & 1550.6 & 0.11 & 1763.8 & 213.2 \\
24.0 & 0.68 & 1238.2 & 0.11 & 1411.0 & 172.8 \\
18.0 & 0.62 & 927.1 & 0.10 & 1058.3 & 131.2 \\
12.0 & 0.57 & 610.0 & 0.09 & 705.5 & 95.5 \\
\hline
\end{tabular}




\section{Motor Speed-Torque}

The torque-speed curve is a common method of graphically displaying motor characteristics. It is generated by plotting the motor speed, current, mechanical output power and efficiency as functions of the motor torque. The following graphs in Figure 1 show the important relationship, that the torque from this type of motor has a maximum value at zero speed and it falls steadily with increasing speed. This maximum torque is also known as stall torque, Ts. Eq. (5) shows the equation of stall torque considering 'no load' losses.

$$
T_{s}=\frac{K_{m} V_{s}}{R_{a}}-T_{f}
$$

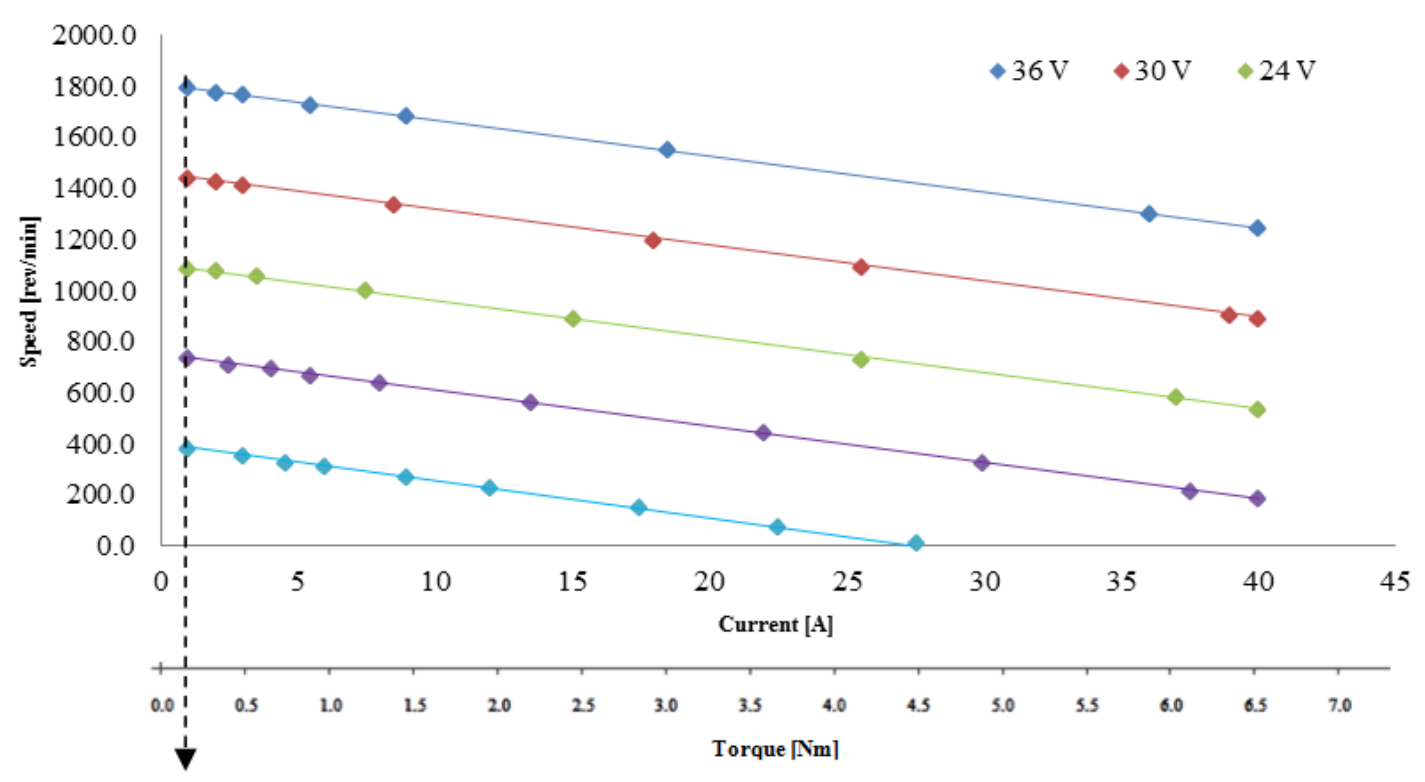

No load condition

Figure 1. Torque-speed curve simulation of the MMP D40-675F.

\section{Motor Efficiency}

The major sources of loss in the brushed DC electric motor are the same as for all types of electric motor, and can be divided into three main categories, as follows. First, there are the copper losses, $P_{\text {copper. }}$ These are caused by the electrical resistance of the wires and brushes of the motor. Second are the iron losses caused by the magnetic effects in the iron of the motor. There are two types of iron loss: The first are hysteresis losses, $P_{\text {iron-hysteresis }}$ and are the energy required to continually magnetize and demagnetize the iron, aligning and re-aligning the magnetic dipoles of the iron; the second are current losses, $P_{\text {iron-eddy }}$ resulting from the fact that the changing magnetic field generates a current in the iron by the normal methods of electromagnetic induction. The third category of loss is that due to friction, $P_{\text {friction }}$ and windage, $P_{\text {windage }}$. There will of course be a friction torque in the bearings and brushes of the motor. The rotor will also have a wind resistance, which might be quite large if a fan is fitted to the rotor for cooling. The sum of these three main losses represents the actual detailed losses occurring in a DC motor. 


$$
\begin{aligned}
& P_{\text {loss }}=P_{\text {copper }}+P_{\text {iron-hysteresis }}+P_{\text {iron-eddy }}+P_{\text {friction }}+P_{\text {windage }} \\
& \eta=\frac{P_{\text {ouy }}}{P_{\text {in }}}=\frac{P_{\text {out }}}{P_{\text {out }}+P_{\text {loss }}}=\frac{\frac{\pi}{30} n T}{I^{2} R_{a}+\frac{\pi}{30} n T_{\text {mag }}+\text { const }^{2}+\frac{\pi}{30} n T_{f}+\text { const } \frac{\pi}{30} n^{3}}
\end{aligned}
$$

However, to ascertain the actual losses from the above calculations is almost impossible if specific data, for example the constant for iron losses, is not known. Iron losses are the most difficult part to calculate requiring a high level of mathematical calculation or the use of motor design software. But this is only possible if the internal design of the motor, including the shape, arrangement, magnetic flux and the iron core design, is known. This information is not provided by any motor manufacturer. Therefore, the authors have chosen a simple technique to estimate the total motor loss by using the actual recorded data in the basic formulation. As is known, efficiency is the ratio of the output power to the input power. Input power is easy to determine where it is a product of the motor's terminal voltage and the motor current. Output power is the product of motor torque and angular speed. In this case, the calculated torque value will be deducted from torque friction $\left(T-T_{f}\right)$ where the torque friction can be determined by the product of motor constant, $K_{m}$ and the actual no load current reading, $I_{o}$. Then, the calculated rotational speed will be deducted from the actual speed loss reading $\left(n-n_{l}\right)$ which was measured during the no load condition. The resulting formula is as shown in Eq.8.

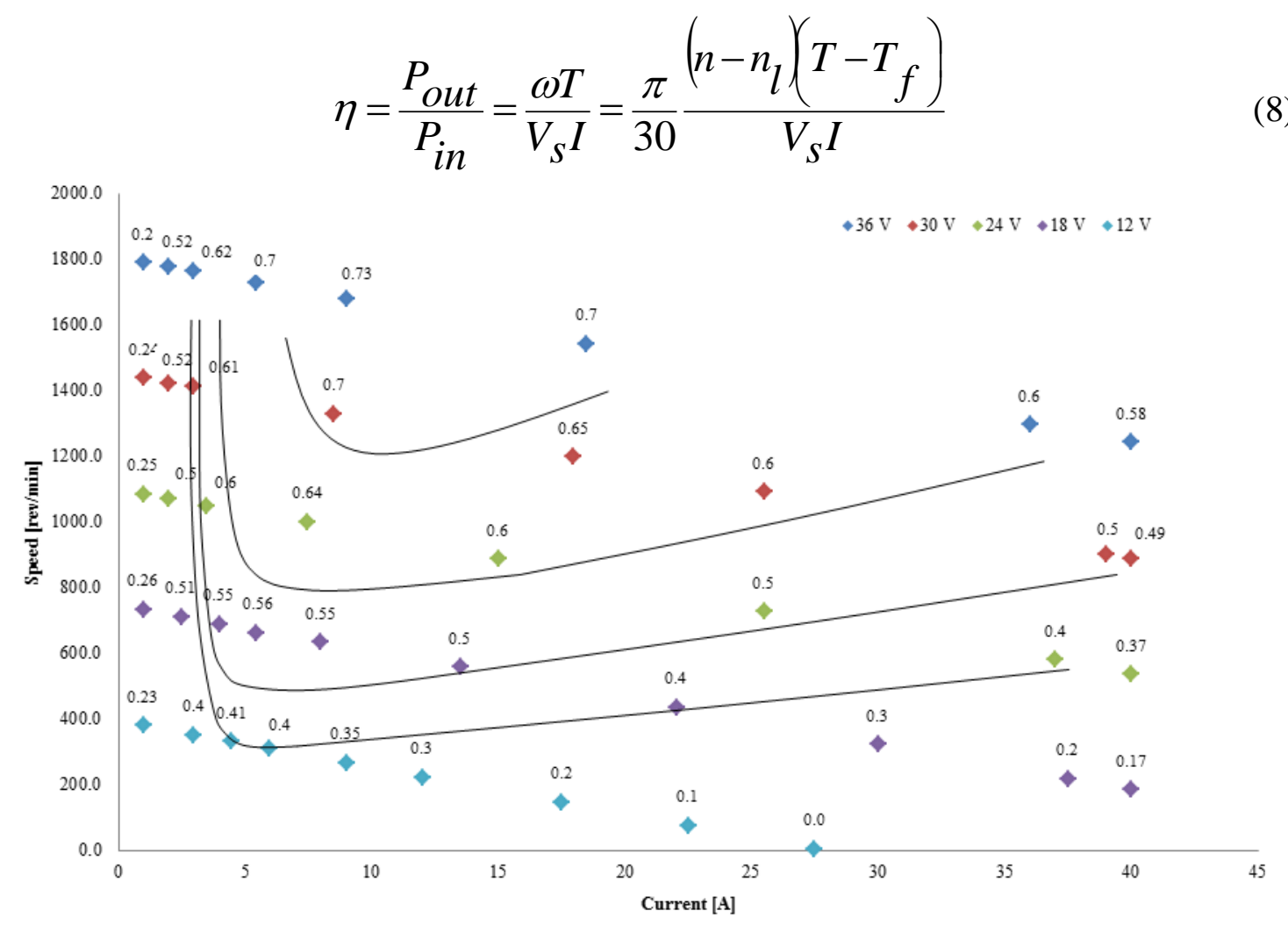

Figure 3. Efficiency map simulation of the MMP D40-675F. 


\section{Experimental Method}

Cruising performance experiments were carried out using a dedicated customized inertia dynamometer. Figure 4 shows a photo of the test bench. It consists of the traction wheel of the vehicle coupled with the DC electric motor via a gear and a continuously-variable transmission (CVT) hub. Therefore, when the motor entrains the traction wheel, it is equivalent to the entrainment of the whole car on the race track. Furthermore, upper mass and flat plates were implemented to simulate rolling resistance and aerodynamic drag to achieve real running conditions. An optical encoder is placed on the inertia wheel to measure its rotational speed by using an Eagle Tree System data logger. The data logger has the ability to log the speed, temperature, current and voltage of the DC motor.

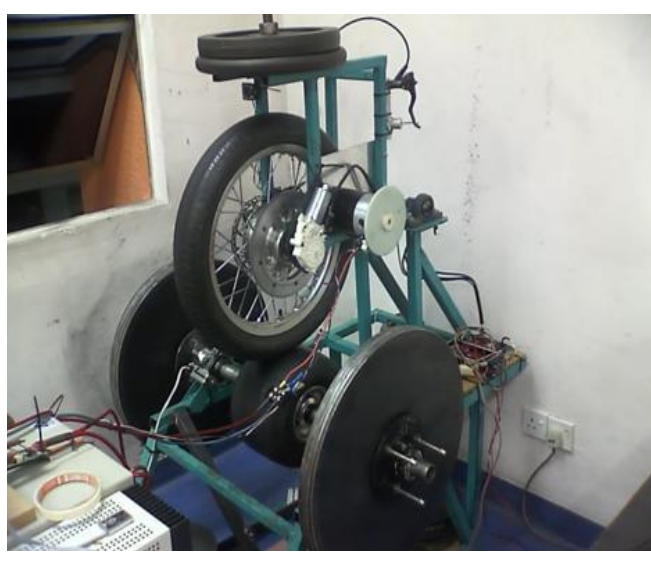

(a)

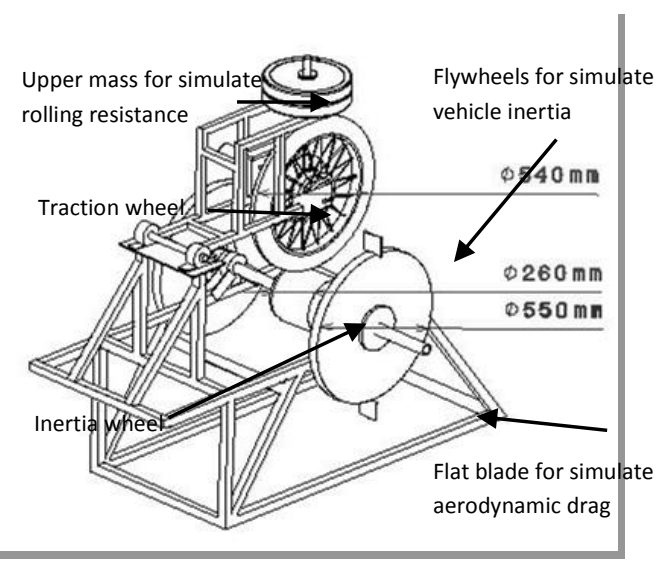

(b)

Figure 4. (a) Photo of the inertia dynamometer. (b) Labeling of the main components on an isometric drawing.

Table 5. Data taken from the Eagle Tree data logger for the $21 \mathrm{~km} / \mathrm{h}$ cruise test with 13 different gear ratios.

\begin{tabular}{llllllll}
\hline No & $\begin{array}{l}\text { CVT Gear } \\
\text { position }\end{array}$ & $\begin{array}{l}\text { Gear } \\
\text { ratio }\end{array}$ & $\begin{array}{l}\text { Power } \\
(\mathrm{W})\end{array}$ & Voltage $(\mathrm{V})$ & $\begin{array}{l}\text { Current } \\
(\mathrm{A})\end{array}$ & $\begin{array}{l}\text { Speed } \\
(\mathrm{rpm})\end{array}$ & $\begin{array}{l}\text { Temp } \\
\left({ }^{0} \mathrm{C}\right)\end{array}$ \\
\hline 1 & 210 & 8.37 & 265.37 & 36.18 & 7.34 & 1749.43 & 41.14 \\
2 & 260 & 7.83 & 256.37 & 34.01 & 7.54 & 1635.60 & 41.59 \\
3 & 310 & 7.32 & 252.94 & 32.10 & 7.88 & 1527.37 & 42.01 \\
4 & 360 & 6.82 & 250.78 & 30.27 & 8.29 & 1424.01 & 42.38 \\
5 & 410 & 6.35 & 247.29 & 28.68 & 8.62 & 1333.87 & 42.80 \\
6 & 460 & 5.90 & 249.68 & 27.10 & 9.21 & 1237.84 & 42.93 \\
7 & 510 & 5.49 & 248.77 & 25.73 & 9.67 & 1155.97 & 43.15 \\
8 & 560 & 5.10 & 250.93 & 24.52 & 10.23 & 1080.58 & 43.40 \\
9 & 610 & 4.75 & 254.09 & 23.50 & 10.81 & 1015.28 & 43.57 \\
10 & 660 & 4.42 & 262.53 & 22.55 & 11.64 & 946.53 & 43.70 \\
11 & 710 & 4.12 & 267.37 & 21.65 & 12.35 & 883.70 & 43.95 \\
12 & 760 & 3.84 & 274.96 & 20.82 & 13.21 & 822.05 & 44.27 \\
13 & 810 & 3.59 & 289.3 & 20.12 & 14.38 & 761.59 & 44.57 \\
\hline
\end{tabular}




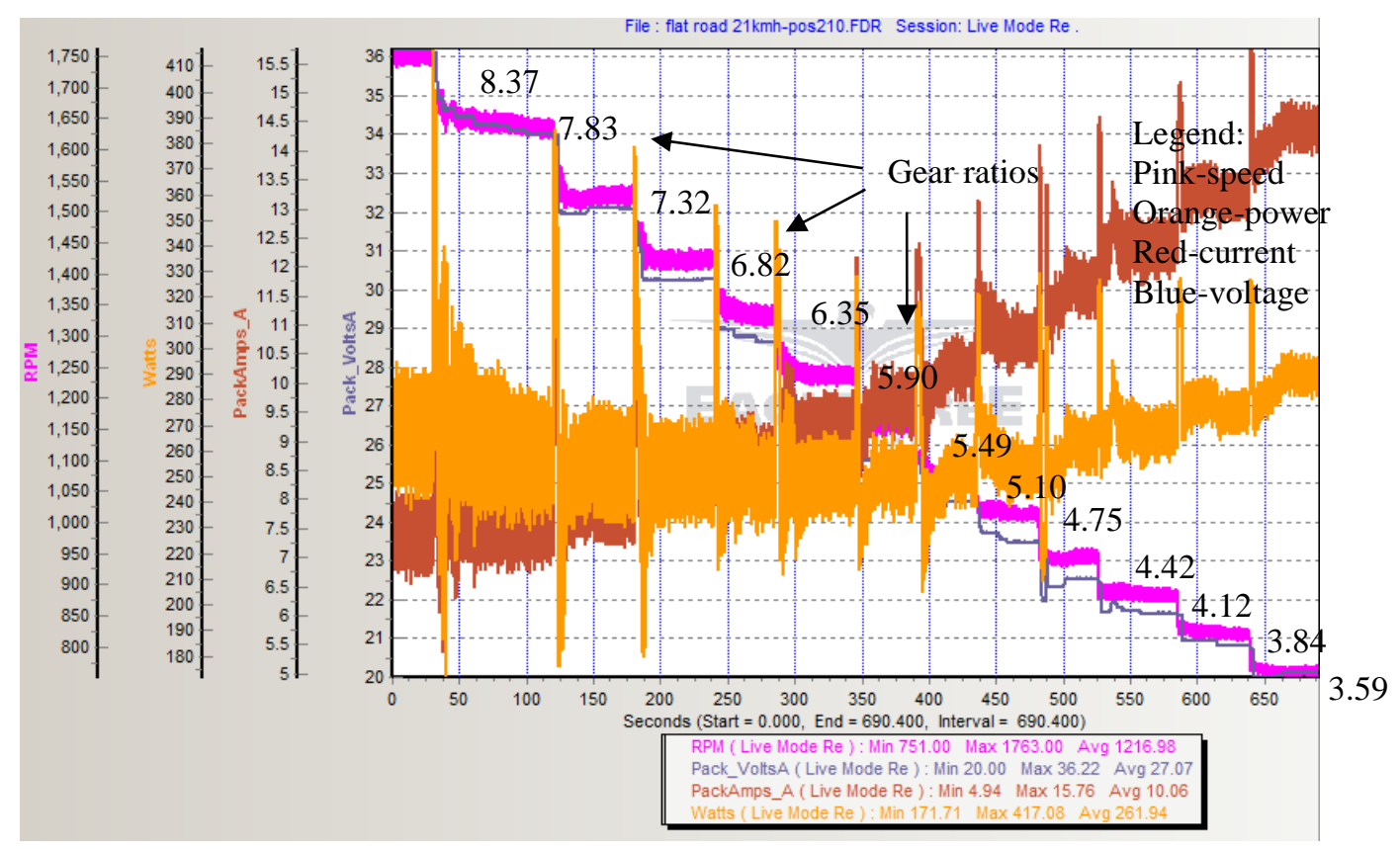

Figure 5. Graphical interface of the Eagle Tree data logger software for a $21 \mathrm{~km} / \mathrm{h}$ cruise test with 13 different gear ratios.

The testing was conducted by running the wheel at a targeted speed. For example, to maintain $21 \mathrm{~km} / \mathrm{h}$ for different gear ratios, the motor voltage is adjusted until it reaches $21 \mathrm{~km} / \mathrm{h}$. Gear ratios can be changed simultaneously while running because of the use of the electronic CVT. As an example, Figure 5 shows the $21 \mathrm{~km} / \mathrm{h}$ testing result with four different lines plotted, where pink represents speed, orange input power, red current, and blue voltage. To show this more clearly, the experimental data is included in tabular form in Table 5. The yellow highlighting shows the reading with the lowest power consumption. This means that the most appropriate gear ratio for a speed of 21 $\mathrm{km} / \mathrm{h}$ is $1: 6.35$.

\section{RESULTS AND DISCUSSION}

Experiments were conducted on a flat road for speed intervals of 21, 23, 25, 28 and 30 $\mathrm{km} / \mathrm{h}$ and a graph of the power against the gear ratio is presented in Figure 6 . The larger symbols in Figure 6 refer to the gear ratios that use the lowest energy for each speed. At a speed of $21 \mathrm{~km} / \mathrm{h}$, it was found that the lowest energy consumption of 300 watt was from a gear ratio of 6.35 . At a speed of $23 \mathrm{~km} / \mathrm{h}$, the best gear ratio was 5.90 . When the vehicle reached a speed of $25 \mathrm{~km} / \mathrm{h}$, the best gear ratio was 5.49 . The 5.49 gear ratio was also the best ratio at a speed of $28 \mathrm{~km} / \mathrm{h}$. Last, a speed of $30 \mathrm{~km} / \mathrm{h}$ showed the best gear ratio of 5.10. Consequently, gear ratio design requires a balance to be achieved between the range, performance, and top speed. Appropriate gear sizing affects overall system efficiency by affecting motor efficiency. The power diversity for the same speed shows that there are differences in the efficiency of the DC motor. The impact of an incorrect gear ratio affects the results giving energy waste. This phenomenon occurs because of the loss occurring in the motor itself. To achieve the same speed using different gear ratios, the motor voltage must be adjusted. Therefore, motor speed and motor torque change can result in a different performance. This explanation can be clearly shown using efficiency maps, as in Figure 7. The experimental results are 
presented in the simulated efficiency map. As can be seen, the best gear ratio is in the area of highest efficiency at more than $70 \%$. This result shows that the selection of the correct gear ratio is important in ensuring that the electric motor is working in the most efficient region. The right gear ratio selection can be made by referring to the efficiency map.

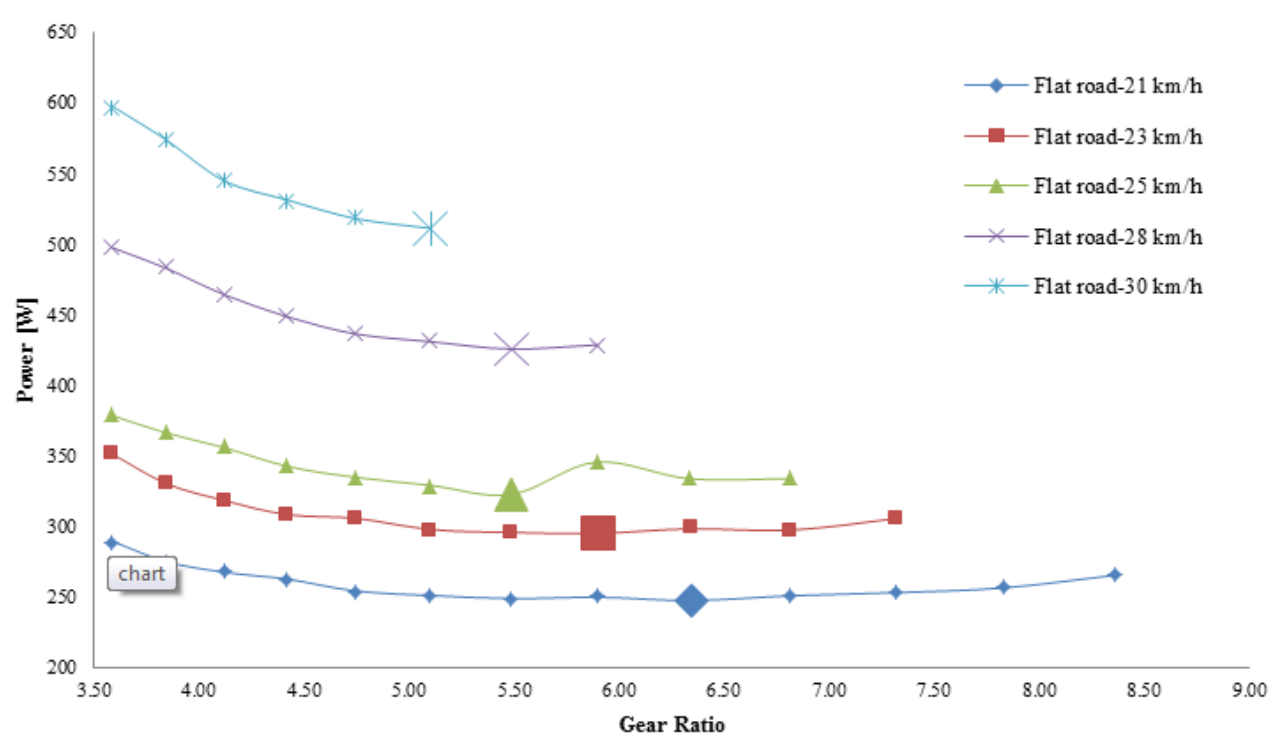

Figure 6: Effect of gear ratio on power consumption on a flat road.

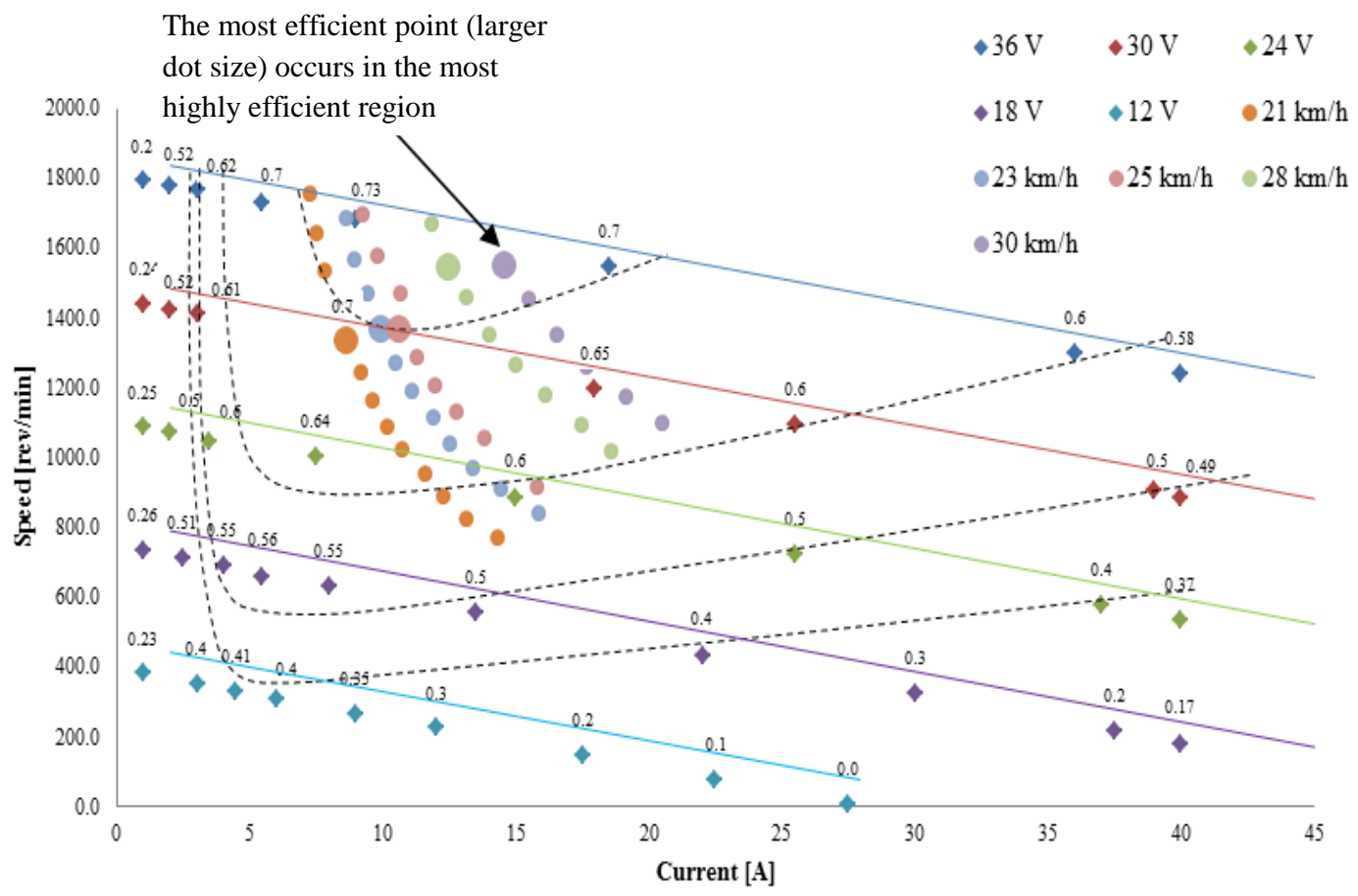

Figure 7. Experimental results plotted on the efficiency map.

Therefore, the use of efficiency maps is very important in producing an efficient electric power train. Not all manufacturers supply efficiency maps to their customers. Thus the technique of estimating efficiency maps by using the basic parameters of the 
electric motor can be useful. The simulated efficiency map we have created shows a fairly accurate result and this is evident when it is compared with the experimental values as in Figure 7.

\section{CONCLUSIONS}

An electric vehicle powered by a PEMFC was developed to drive a lightweight electric vehicle for constant speed cruising. The feasibility of such an open-cathode fuel cell as the main power for the vehicle and drive trains is the electric traction motor. Traction motors should meet requirements such as high instant power, high power density and high torque at low speed for starting and climbing [16]. This contribution mainly focuses on the dynamic performance of the vehicle in laboratory tests using different gear ratios. Based on the systematic experiments and analysis, the following conclusions can be drawn:

i) Appropriate gear sizing affects the overall system efficiency by affecting motor efficiency. It shows each different speed has a different optimum ratio to ensure the highest vehicle performance.

ii) The selection of the correct gear ratio is important to ensure that the electric motor works in the most efficient region. The results show that the best gear ratio is in the highest efficiency region of the efficiency map at more than $70 \%$.

iii) The use of a programmable CVT can help the electric motor always to operate at the point of maximum efficiency.

iv) It is concluded that the efficiency map is the best tool to configure the best gear ratio. Efficiency maps can be constructed simply by using the 'no load' condition taken from the actual testing.

\section{ACKNOWLEDGEMENTS}

The financial support of the given for this work by the Universiti Teknologi MARA under the Tabung Amanah HEP and Tabung Amanah Pembangunan Akademik HEA in the year of 2014 for this research development and also MOE FRGS grant (FRGS/2/2014/TK06/UITM/02/) for supporting this manuscript is gratefully acknowledge.

\section{REFERENCES}

[1] Hwang JJ, Chen YJ, Kuo JK. The study on the power management system in a fuel cell hybrid vehicle. International Journal of Hydrogen Energy. 2012;37:4476-89.

[2] Pollet BG, Staffell I, Shang JL. Current status of hybrid, battery and fuel cell electric vehicles: from electrochemistry to market prospects. Electrochim Acta. 2012;84:235-49.

[3] Van Vliet OP, Kruithof T, Turkenburg WC, Faaij AP. Techno-economic comparison of series hybrid, plug-in hybrid, fuel cell and regular cars. Journal of Power Sources. 2010;195:6570-85.

[4] Ghobadian B, Najafi G, Nayebi M. A semi-empirical model to predict diesel engine combustion parameters. Journal of Mechanical Engineering and Sciences. 2013;4:373-82. 
[5] Kalyani Radha K, Naga Sarada S, Rajagopal K, Nagesh EL. Performance and emission characteristics of CI engine operated on vegetable oils as alternative fuels. International Journal of Automotive and Mechanical Engineering. 2011;4:414-27.

[6] Mohamed WANW, Atan R. Polymer electrolyte membrane fuel cell. International Journal of Automotive and Mechanical Engineering. 2012;5:64859.

[7] Kamil M, Rahman MM, Bakar RA. Integrated simulation model for composition and properties of gases in hydrogen fueled engine. International Journal of Automotive and Mechanical Engineering. 2013;8:1242-155.

[8] Azad A, Ameer Uddin S, Alam M. A Comprehensive Study of Di Diesel Engine Performance With Vegetable Oil: An Alternative Bio-Fuel Source of Energy. International Journal of Automotive and Mechanical Engineering. 2012;5:57686.

[9] Kamil M, Rahman MM, Bakar RA. Performance evaluation of external mixture formation strategy in hydrogen fueled engine. Journal of Mechanical Engineering and Sciences. 2011;1:87-98.

[10] Rahim R, Mamat R, Taib MY, Abdullah AA. Influence of fuel temperature on a diesel engine performance operating with biodiesel blended. Journal of Mechanical Engineering and Sciences. 2012;2:226-36.

[11] Ho T, Karri V, Lim D, Barret D. An investigation of engine performance parameters and artificial intelligent emission prediction of hydrogen powered car. International Journal of Hydrogen Energy. 2008;33:3837-46.

[12] Ho T, Karri V. Basic tuning of hydrogen powered car and artificial intelligent prediction of hydrogen engine characteristics. International Journal of Hydrogen Energy. 2010;35:10004-12.

[13] Kapilan N, Ashok Babu TP, Reddy RP. Improvement of performance of dual fuel engine operated at part load. International Journal of Automotive and Mechanical Engineering. 2010;2:200-10.

[14] Nematizade P, Ghobadian B, Najafi G. Investigation of fossil fuels and liquid biofuels blend properties using artificial neural network. International Journal of Automotive and Mechanical Engineering. 2012;5:639-47.

[15] Tirnovan R, Giurgea S. Efficiency improvement of a PEMFC power source by optimization of the air management. International Journal of Hydrogen Energy. 2012;37:7745-56.

[16] Corbo P, Migliardini F, Veneri O. Performance investigation of $2.4 \mathrm{~kW}$ PEM fuel cell stack in vehicles. International Journal of Hydrogen Energy. 2007;32:4340-9.

[17] Akyalçın L, Kaytakoğlu S. Optimization of structural combinations on the performance of a PEMFC's MEA. Journal of Power Sources. 2008;180:767-72.

[18] Abdullah NR, Shahruddin NS, Mamat R, Ihsan Mamat AM, Zulkifli A. Effects of air intake pressure on the engine performance, fuel economy and exhaust emissions of a small gasoline engine. Journal of Mechanical Engineering and Sciences. 2014;6:949-58.

[19] Hairuddin AA, Wandel AP, Yusaf T. An Introduction to a Homogeneous Charge Compression Ignition Engine. Journal of Mechanical Engineering and Sciences. 2014;7:1042-52.

[20] Chan C. Overview of Electric Vehicles-Clean and Energy Efficient Urban Transportation. PEMC'96. Budapest, Hungary1996. p. 7-15. 
[21] Larminie J, Lowry J. Electric vehicle technology explained: John Wiley \& Sons; 2004.

[22] Karatzaferis JC, Lampropoulos LS, Tatakis EC. Efficiency improvement in DC and AC motor powered electric vehicles. Proceedings of the 2011-14th European Conference on Power Electronics and Applications (EPE 2011): IEEE; 2011. p. 1-10.

[23] Chau K, Chan C, Liu C. Overview of permanent-magnet brushless drives for electric and hybrid electric vehicles. IEEE Transactions on Industrial Electronics. 2008;55:2246-57.

[24] Kamachi M, Miyamoto H, Sano Y. Development of power management system for electric vehicle "i-MiEV". International Power Electronics Conference IEEE; 2010. p. 2949-55. 